\title{
Analysis of the Needs of Parents Who Have Cerebral Palsy Children Reviewed from the Family Counseling
}

\author{
Nurhastuti \\ Departement of Special Education \\ Universitas Negeri Padang, Indonesia \\ nurhastuti@fip.unp.ac.id \\ Mega Iswari \\ Departement of Special Education \\ Universitas Negeri Padang, Indonesia \\ mega.iswari@yahoo.com
}

\author{
Kasiyati \\ Departement of Special Education \\ Universitas Negeri Padang, Indonesia \\ kasiyati@fip.unp.ac.id

\section{Zulmiyetri} \\ Departement of Special Education \\ Universitas Negeri Padang, Indonesia \\ zulmiyetri@fip.unp.ac.id
}

\author{
Irdamurni \\ Departement of Special Education \\ Universitas Negeri Padang, Indonesia \\ irdamurni@fip.unp.ac.id
}

\begin{abstract}
Sometimes parents experience hopeless care in children with cerebral palsy. Some of parents feel shocked and cannot accept the fact that their child has a disability. Therefore, we need an analysis of the parents' need. Therefore, we need an analysis of the needs of parents who have children with cerebral palsy. In order to understand how the parents' needs, it is considered to use family counseling that is appropriate to the cultural background and socio-economic level of the family. The purpose of this study is to explain the needs of parents who have children with cerebral palsy. This research is a quantitative study, namely research that uses explanatory research because this research was conducted in the city of Padang with a total sample of 13 parents who had children with cerebral palsy. The source of the data came from distributing questionnaires after family counseling was conducted to parents. The results showed that parental needs consist of several indicators, namely acceptance of parents who have children with cerebral palsy, factors that influence parents in receiving their children, problems and obstacles faced by parents in dealing with their children with cerebral palsy.
\end{abstract}

Keywords: analysis of the needs, parents, cerebral palsy, family counseling

\section{INTRODUCTION}

Parents are responsible as the main educators for the development of their children who have cerebral palsy even though the presence of cerebral palsy children in the family is not something that is expected. But sometimes parents experience hopeless care in cerebral palsy children. Some parents feel shocked and cannot accept the fact that their child has a disability. Therefore we need an analysis of parents' needs.

Need analysis is a constructive and positive means for making changes. According to (Ghoreyshyzadeh, Hosein Pour Feizi, Ghaffari, \& Nourdadgar, 2017), need analysis is the process of gathering information on gaps and prioritizing these gaps to be solved." With this needs analysis it is expected that parents can educate and develop cerebral palsy children to live independent and ready to get along in the community.

One way that can be done in the analysis of the parents' needs is by family counselling. In order to understand how the parents' needs, it is important to use family counselling that is appropriate to the cultural background and socio-economic level of the family. According to Willis (2009), one of the goals of family counselling is, "Developing tolerance for family members who are experiencing problems in life caused by the family itself or outside the family.

\section{METHOD}

This research is a quantitative research, namely research that uses explanatory research because this research attempts to explain the parents' needs. This research was conducted in the city of Padang with a total sample of 13 parents.

After conducting family counselling on 13 parents who have children with cerebral palsy, the questionnaire was distributed to determine the needs of parents in carrying out education and coaching for their children who have cerebral palsy. Questionnaire contains 114 questions concerning the parents' needs.

\section{RESUlts}

This study has three measurement indicators, namely the acceptance of parents, factors that influence parents in receiving their children who have cerebral palsy, and the problems and obstacles faced by parents in dealing with their children with cerebral palsy. The three indicators are described in the results of the study as follows.

a. Acceptance of Parents 
The research question about the acceptance of parents consists of several aspects, namely respecting the child as a whole, understanding the child uniquely, recognizing the needs of the child and loving children who are independent, and loving children without conditions. The results of the questionnaire on the acceptance of parents who have children with cerebral palsy can be seen in the Table 1.

Based on Table 1 above, it can be explained that most respondents have accepted that their children have cerebral palsy. Based on the analysis of respondents' answers to this problem, it is known that the respondents have respected the needs of children and encouraged children to be independent. However, there are some respondents who do not respect the differences in children individually and respect the ideals and hopes of children.

b. Factors that Influence Parents in Receiving their Children

Research questions about the factors that influence parents in accepting their children whose cerebral palsy consists of several aspects, namely knowledge of cerebral palsy, knowledge of mentoring at home, and access to information on children's self-development. The results of the questionnaire about the factors that influence parents in receiving their children with cerebral palsy can be seen in the Table 2.

Based on table 2 above, it can be explained that most of the respondents already know the factors that influence parents in receiving their children. Based on the analysis of the respondents' answers to this problem, it is known that the respondents already knew the expectations of cerebral palsy children, and the opportunities for education and employment for children with cerebral palsy.

c. The problems and obstacles faced by parents in dealing with their children with cerebral palsy.

Research questions about problems and constraints faced by parents, consists of several aspects, namely internal and external. The results of the questionnaire about the problems and obstacles faced by parents in dealing with their children with cerebral palsy can be seen in the Table 3.

Table 1

Distribution of Respondents' Answer Distribution

\begin{tabular}{|c|c|c|c|c|c|c|}
\hline \multirow{2}{*}{ Aspect } & \multirow{2}{*}{ Item Number } & \multicolumn{4}{|c|}{ Respondent's Answer } & \multirow{2}{*}{ Total } \\
\cline { 3 - 7 } & & Never & Some-times & Often & Always \\
\hline Acceptance of parents & $1-35$ & 41 & 64 & 126 & 224 & 455 \\
\hline \multicolumn{2}{|r|}{)} & $\mathbf{9 , 0}$ & $\mathbf{1 4 , 1}$ & $\mathbf{2 7 , 7}$ & $\mathbf{4 9 , 2}$ & $\mathbf{1 0 0}$ \\
\hline
\end{tabular}

Table 2

Distribution of Respondents' Answer Distribution

\begin{tabular}{|c|c|c|c|c|c|c|}
\hline \multirow[b]{2}{*}{ Aspect } & \multirow{2}{*}{ Item Number } & \multicolumn{4}{|c|}{ Respondent's Answer } & \multirow[b]{2}{*}{ Total } \\
\hline & & Never & Some-times & Often & Always & \\
\hline Factors that influence parents & $36-61$ & 58 & 45 & 71 & 164 & 338 \\
\hline & $\%$ & 17,2 & 13,3 & 21,0 & 48,5 & 100 \\
\hline
\end{tabular}

Table 3

Distribution of Respondents' Answer Distribution

\begin{tabular}{|c|c|c|c|c|c|c|}
\hline \multirow{2}{*}{ Aspect } & \multirow{2}{*}{ Item Number } & \multicolumn{4}{|c|}{ Respondent's Answer } \\
\cline { 3 - 7 } & & Never & Some-times & Often & Always & \multirow{2}{*}{ Total } \\
\hline The problems and obstacles & $62-114$ & 174 & 81 & 164 & 376 & 795 \\
\hline \multicolumn{2}{r}{$\%$} & 21,9 & 10,2 & 20,6 & 47,3 & 100 \\
\hline
\end{tabular}

Based on Table 3 above, it can be explained that most of the respondents experienced many problems and obstacles faced by parents in facing their children. Based on the analysis of the respondents' answers to this problem, it is known that the respondents understand the physical, psychological, emotional, social relations, communication and learning characteristics, are able to provide motivation and ideals of life, and understand the types of opportunities and work placement / career for cerebral palsy children.

\section{Discussion}

Children's health conditions, such as disability in children, are one of the conditions of children that can affect the parents' quality life (Lee et al., 2010). Some studies show that disability in children will affect the mother's quality life. Guillamon, et al. (2013) study stated that self-efficacy and strategy in dealing with problems in parents of children with cerebral palsy will affect their quality of life. Self-efficacy is a feeling of competency and ability to control oneself. This belief is useful for one's success in working on tasks and improving self-welfare (Ones, Yilmaz, Cetinkaya, \& Caglar, 2005).

Parents are family members who become natural caregivers for children with cerebral palsy (Purbo, 2017). Mothers are ordinary figures who are the main caregivers for them. Feeling care to children with cerebral palsy makes the mother vulnerable to psychological and physical stress. The time for mothers to develop social relationships and spend time on themselves will decrease when caring for children with cerebral palsy. This condition makes the quality of life of mothers tend to be poor.

Having a cerebral palsy child is not something to be regretted but must be used as a test that must be faced with full determination so that cerebral palsy children become independent and successful like other normal children (Karadağ Saygi, Gıray, Peynırcıcerşıt, Ulutatar, \& Aydin, 2015) The fact that families play an important role in the lives of children with disabilities is an increasingly important view. The level of family education, sociocultural status, and the psychological approach of parents 
play an important role in the development of children with cerebral palsy.

Parents need to know what needs to be taken care of their children (Nahm, Graham, Gormley, \& Georgiadis, 2018) The purpose of analyzing parental needs about cerebral palsy children is not to cure their barriers to normal conditions but to improve the function, ability, and maintain health such as independence, movement, development, cognitive, and independence. Parents need knowledge and experience as a framework for strengthening interventions in addressing the problems they experience when managing cerebral palsy children.

Based on the results of the study, the actual problems being faced can be identified and solved. Therefore, the following will be elaborated on each of these aspects of the solution and improvement.

\section{a. Acceptance of Parents}

Based on the research, there are still parents who have not fully accepted the children of cerebral palsy as a whole. Parents who have cerebral palsy children are not easy to accept the reality they experience. To be able to receive their children, time and effort are needed. Parents also go through various stages to arrive at the acceptance stage.

Family counselling has a positive role in this problem. Through family counselling, we can find out some of the needs of parents who have children with cerebral palsy related to the acceptance of parents who have children with cerebral palsy, namely: (1) Parents are aware of their child's abnormal condition and try to acknowledge that their child's condition is God's will; (2) Looking for a solution by consulting a doctor, therapist and psychologist; (3) The task of parents in giving attention and affection, treating them specifically, giving encouragement and supporting their children to recover by participating in therapy; and (4) Parents provide opportunities for children to express their feelings.

b. Factors that influence parents in receiving their children

This study shows that there are still parents who have children with cerebral palsy who have not been aware of many factors that affect themselves to receive cerebral palsy children in the family. Through family counselling, there can be found a number of needs for parents who have children with cerebral palsy that are related to factors that influence the acceptance of children with cerebral palsy, namely: (1) Education and experience of parents are needed in help and care to children with cerebral palsy; (2) Free time to communicate with children openly, placing children in important positions in the home; (3) Try to get children to be well received in the family and community environment; and (4) Suitability of the atmosphere to support the needs of parents in managing children with cerebral palsy.

c. The problems and obstacles faced by parents in dealing with their children with cerebral palsy

Based on research, there are still parents who face problems and obstacles of their children. Through family counselling can be found several needs of parents who have children with cerebral palsy related to problems and obstacles in dealing with children with cerebral palsy, namely: (1) the need for knowledge in managing children with cerebral palsy; (2) the need for assistance; (3) the need for access to information on children's selfdevelopment; and (4) the need for opportunity access and job placement for children with cerebral palsy.

\section{Conclusion}

There are several aspects to the needs of people who have children with cerebral palsy. Judging from the indicators of acceptance of parents who have children with cerebral palsy, parents need to be aware of the abnormal condition of their children, seek a solution by consulting doctors, therapists and psychologists, the task of parents in giving attention and affection, and parents giving opportunities to children to express their feelings.

Judging from the indicators of the factors that influence parents in accepting their children with cerebral palsy, the parents' needs are education and parental experience, free time to communicate with children openly, trying to make children well-received in the family and community environment, suitability to support the needs of parents in managing cerebral palsy children. Judging from the indicators of factors that influence parents in accepting their children with cerebral palsy, the parents' needs are knowledge in managing cerebral palsy children, mentoring, access to information on children's self-development, access to opportunities and job placement for children with cerebral palsy.

\section{REFERENCES}

[1] Ghoreyshyzadeh, F., Hosein Pour Feizi, A. A., Ghaffari, R., \& Nourdadgar, A. (2017). Educational Needs Assessment of Family Health Providers in Tabriz Health Care Centers in 2015. Research and Development in Medical Education, 6(1), 12-18. https://doi.org/10.15171/rdme.2017.003

[2] Karadağ Saygi, E., Gıray, E., Peynırcıcerşıt, H., Ulutatar, F., \& Aydin, R. (2015). Serebral palsili çocuğu olan ailelerin aile ortamlarının değerlendirilmesi ve gereksinimlerinin belirlenmesi. Turkiye Fiziksel Tip ve Rehabilitasyon Dergisi, 61(4), 320-325. https://doi.org/10.5152/tftrd.2015.70745

[3] Nahm, N. J., Graham, H. K., Gormley, M. E., \& Georgiadis, A. G. (2018). Management of hypertonia in cerebral palsy. Current Opinion in Pediatrics, 30(1), 57-64. https://doi.org/10.1097/MOP.0000000000000567

[4] Ones, K., Yilmaz, E., Cetinkaya, B., \& Caglar, N. (2005). Assessment of the quality of life of mothers of children with cerebral palsy (primary caregivers). Neurorehabilitation and Neural Repair, 19(3), 232-237. https://doi.org/10.1177/1545968305278857

[5] Lee, P. C., Lee, T. C., Chen, V. C. H., Chen, M. L., Shih, D. H., Shao, W. C., \& Lee, M. C. (2010). Quality of life in mothers of children with oppositional defiant symptoms: a community sample. Mental health in family medicine, 7(2), 93.

[6] Purbo, L. (2017). Hubungan Antara Kepribadian Tangguh dengan Kualitas Hidup pada Ibu yang Memiliki Anak Cerebral Palsy. (August).

[7] Willis, S. S. (2009). Konseling Keluarga (Family Counseling). Bandung: Alfabeta. 